\title{
Proposed Educational Strategies for A Reformed Pharmacy Curriculum Based on Graduate's Self-Perceived Assessment of Pre-Service Education
}

\author{
Abdulla S. Bin-Ghouth \\ Chairman, Department of Community Medicine, Hadhramout University College of Medicine, Mukalla, Yemen \\ Ghanim Y. Alsheikh* \\ WHO Collaborating Centre for Public Health Education and Training, Imperial College London, UK. \\ Former Dean, Hadhramout University College of Medicine, Mukalla, Yemen \\ Email: alsheikhg@gmail.com \\ Ali M. Batarfi \\ Dean, Department of Surgery, Hadhramout University College of Medicine, Mukalla, Yemen
}

\begin{abstract}
Introduction: Pharmacy practice witnessed dramatic significant changes over the past years worldwide. The traditional role of the pharmacist involving preparation, dispensing and selling of medications is no longer adequate. This has evolved into direct involvement of the pharmacist in the design, implementation, and monitoring of therapeutic plans to produce specific care outcomes. The Bachelor degree in pharmacy at the University of Aden, Yemen, witnessed scarce reviews or evaluation studies on graduates and curriculum introduced in 1995 and unchanged till 2018. Objectives: To (1) assess perception of pharmacists, working in Aden, of their pre-service education and its relevance to current work and (2) analyze the available benchmarks and propose educational strategies that could be addressed in designing and adopting a reformed pharmacy preservice curriculum in light of results of the study. Methods: A self-administered questionnaire distributed to 220 pharmacists working in urban Aden city with response rate 86\% $(n=189)$. Questions covered general personal information; perception of pre-service educational subjects/courses and their relevance to current job; status of respondents' practice of skills and attitudes acquired during their study. Analysis of the 7-star role of pharmacist is done based on results of the study. Results: Practicing pharmacists work in 5 different settings in Aden, in community pharmacy, hospital pharmacy, industrial pharmaceutics, management of medicines and medical supplies and academic pharmacy. Majority marked existence of weak linkage between preservice curriculum and daily work demands. 16 out of the 17 basic sciences were not used in work and to a lesser degree, similar results of pharmaceutical sciences, skills and attitudes. Accordingly, seven educational strategies are proposed. Conclusion: The study showed that pharmacists working in Aden, Yemen, need different knowledge, skills and attitude to be able to perform the current job demands. The results also showed weak link between education and job practice. One of the main challenges facing pharmacy education is the adoption of educational strategies that respond to lack of active acquisition of the needed competencies to produce a "fit-for-purpose pharmacy graduate." Keywords: pharmacy, pre-service, education, reform, strategies
\end{abstract}

DOI: $10.7176 / \mathrm{JHMN} / 76-01$

Publication date:June 30th 2020

\section{Introduction}

Pharmacy, as a profession, has witnessed a dramatic significant change over the past years worldwide. The traditional role of the pharmacist that involves the preparation, dispensing and selling medications is no longer adequate for the pharmacy profession to survive [FIP, 2000]. This has evolved into a direct involvement of the pharmacist in the design, implementation, and monitoring of a therapeutic plan to produce a specific therapeutic outcome. The philosophy of pharmaceutical care has been accepted worldwide as the primary mission of pharmacy. The pharmaceutical care mandates that practitioners not only to dispense medications, but also assume responsibility for improving the quality of patients' outcomes [Hepler and Strand, 1990]. This means that the role of the pharmacist has evolved from that of a compounder and supplier of pharmaceutical products towards that of a provider of services and information and ultimately that of a provider of patient care as an active member of the health team.

In order to fulfill such a transition of role, the graduating pharmacist needs to be able to play other different roles [Toklu and Hussain, 2013]. The concept of the "seven-star pharmacist" that was introduced by the World Health Organization-WHO in 1997 [WHO, 1997] and was taken up by the International Pharmaceutical Federation or Fédération Internationale Pharmaceutique-FIP in 2000 in formulating its policy statement on "Good Pharmacy Education Practice" [FIP, 2000]. The 7-star concept envisages the pharmacist as a caregiver, a decision- 
maker, a communicator, a leader, a manager. a life-long learner and a teacher.

The knowledge base of pharmacy graduates is changing. As these graduates move into practice, so pharmacy practice itself will change, to reflect the new knowledge base. However, pharmacists already in practice were mainly educated on the basis of the old paradigm of pharmaceutical product focus. If these pharmacists are to contribute effectively to the new patient-centred pharmaceutical practice, they must have the opportunity to acquire the new knowledge and skills required for their new role. To achieve this, they need to become life-long learners which is one of the important roles of the new pharmacist. [Kheir et al, 2008]

The changes in the pharmacist's role and functions must be reflected in the basic and continuing education of pharmacists with a focus on student's learning rather than on teacher's teaching. The new model for pharmacy requires that nowadays and future pharmacists are far more than being mere experts in pharmaceutical chemistry and pharmaceutics. They have to realize and apply the principles behind all the activities necessary to manage drug therapy. [FIP, 2000] A study of pharmacy education in 13 countries of the Middle East concluded that Advancements in pharmacy practice should be concurrent and synchronized with the improvements to pharmacy education in this region. [Kheir et al, 2008]

The movement towards the patient care approach has occurred to varying degrees in some countries such as the USA and UK [CPPE, 2014]. It encompasses care in its widest application and pharmacy curricula have long been neglected at many learning institutions, which has helped perpetuate the undervalued status of pharmacists in the health care sector, particularly in developing countries. In traditional pharmacy curricula, the emphasis is often on the technical aspects of pharmacy, rather than on abilities to perform professional practice [6-Junglnicker, 2009]. Pharmacy education in Yemen has been fronting different major challenges and difficulties in providing the right quality and quantity of clinical educational experiences since the establishment of the first bachelor degree study at the university of Sanaa'a University in 1987 [Al-Worafi, 2013). In the context of this paper, the main challenges are imbedded in teaching style and nature of the curricula which have failed to match the needs of the community and the national health care system. The failure to shift from traditional drug-dispensing to a patientcentred approach in pharmacy practice is still the prevailing [Al-Worafi, 2013 and 2014]

The Bachelor degree in pharmacy at the University of Aden, was established in 1995 and since that time more than 1500 pharmacists have graduated and most of them are working inside the country. No reviews or evaluation studies on the original curriculum are available. [Aden University, 2018] Also, detailed studies are unavailable on neither evaluation of graduates nor on exploration of feedback from practicing pharmacists on their basic pharmacy education. [Al-Worafi, 2013]. As stated in a report issued by the Faculty of Pharmacy at Aden University, the curriculum did not change between its establishment in 1995 and 2018 when a revised curriculum was introduced in the academic year 2018-2019 [Aden University, 2018]. The aims of this study is to (1) assess the perception and the level of satisfaction of pharmacists, working in Aden, with their pre-service education at pharmacy colleges and the relevance of its curriculum elements to their current work and (2) to analyze the available benchmarks and propose educational strategies that could be adopted in designing and adopting a reformed pharmacy pre-service curriculum.

\section{Methods}

This work has been conducted through developing an assessment tool (questionnaire) and inviting a number of practicing pharmacists in urban areas of Aden governorate to fill the questionnaire. Pharmacists were invited to participate regardless of their place of their preservice education whether inside or outside the country. The questionnaire is mainly composed of close-ended questions with fewer open-ended questions mainly on personal data. Questions were categorized to test how useful, to pharmacists in their daily work, the knowledge, skills and attitudes studied in pre-service education. The scientific, pharmaceutical subjects were based on Aden curriculum since its establishment in 1995 [Al-Worafi, 2014]. The questions were arranged into three parts as follows:

- Part 1: General personal information on the participants' personal characteristics, their education and their current job category.

- Part 2: Perception of respondents on pre-service educational subjects/courses and their relevance to current job and how useful to participants in their daily work.

- Part 3: Status of respondents' practice of skills and attitudes acquired during their preservice study.

Copies of the self-administered questionnaire were distributed to different health establishments where pharmacists work in urban areas of the city of Aden. Five health workers who received appropriate training ahead of the execution of the project, distributed and collected the completed questionnaires. Computerized data base was designed by using SPSS version 10 software. Data collection was completed before the 2014 political unrest and insurgency that prevailed the country since. A total of 220 copies were distributed. After checking, a total of 189 questionnaires were found to be completely filled. The rest of the questionnaires 31 in number) were discarded because of incompleteness with a response rate of $86 \%$. All the completed questionnaires were checked, entered into database and analyzed in the Department of Community Medicine, Hadhramout University College of Medicine, Mukalla, Yemen. 


\section{Findings}

\subsection{General Overview}

The mean age of the participated pharmacists are 31.13 years (SD 6.05 years, range $24-53$ years) with a total of 131 out of 189 pharmacists are males (69\%). The sample study of 189 pharmacists indicated that they work in a total of 244 job position. As shown in table 1, most of those working in community pharmacies also hold dual work in positions in 4 public sector settings as shown in figure 1 and table 1 . Half of the job positions (122) were found to be working in private sector. As shown in table 1, the pharmacists work in 5 work settings and 18 specialties namely: private community pharmacy (50\%), health administration at the Ministry of Health $(24 \%)$, industrial pharmacy $(21 \%)$, hospital pharmacy (16\%), and academic pharmacy (3\%).

A total of 116 out of 189 sample of pharmacists $(83 \%)$ were found to have graduated from Aden University (figure 2). Most of participants have only a Bachelor degree of pharmacy and pharmaceutical sciences (179/189, 95\%); while only 9 have Master's degree and only one pharmacist has a $\mathrm{PhD}$ degree. Analysis of the completed questionnaire also revealed information on postgraduate and on-job training. Only 39 out of 189 participants (21\%) admitted attending any training course or workshop after graduation. Small number of pharmacists admitted attending training opportunities on important areas like essential medicines (12\%), training on national medicines policy $(5 \%)$ and training on rational use of drugs $(13 \%)$. About $53 \%$ of the participants did not start working immediately after graduation but spent a mean period of 4.6 months before being assigned to a job.

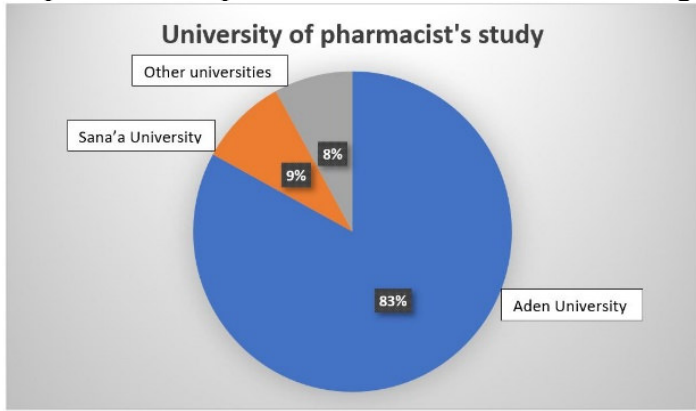

Figure No 2: University of graduation.

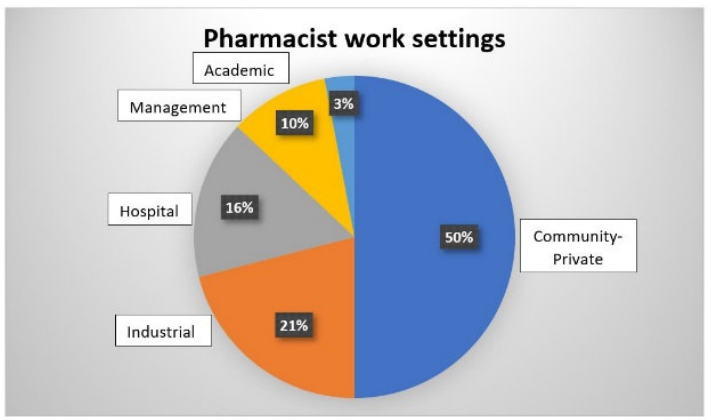

Figure No 1: Work settings. 
Table No 1: A total of 244 settings of work taken by the 189 Pharmacists.

\begin{tabular}{|c|c|}
\hline Pharmacy setting & No. (\% out of 244$)$ \\
\hline \multicolumn{2}{|l|}{ Industrial pharmacy } \\
\hline Drug promotion (Representatives) & $34(14 \%)$ \\
\hline Quality control & $10(4 \%)$ \\
\hline Drug information & $5(2 \%)$ \\
\hline Research \& development & $2(1 \%)$ \\
\hline (2) & $51(21 \%)$ \\
\hline \multicolumn{2}{|l|}{ Community pharmacy } \\
\hline Part-time pharmacist (dual) & $72(30 \%)$ \\
\hline Pharmacist in charge & $28(11 \%)$ \\
\hline Owner of pharmacy & $22(9 \%)$ \\
\hline Total & $122(50 \%)$ \\
\hline \multicolumn{2}{|l|}{ Hospital pharmacy } \\
\hline Inpatient pharmacy & $23(9 \%)$ \\
\hline Outpatient pharmacy & $8(3 \%)$ \\
\hline Emergency pharmacy & $6(3 \%)$ \\
\hline Central pharmacy & $3(1 \%)$ \\
\hline Total & $40(16 \%)$ \\
\hline \multicolumn{2}{|l|}{ Ministry of Health (Management) } \\
\hline Drug management & $15(6 \%)$ \\
\hline Drug information & $4(2 \%)$ \\
\hline Drug procurement & $3(1 \%)$ \\
\hline Storage: medicines and medical supplies & $1(0.4 \%)$ \\
\hline Distribution of medicine & $1(0.4 \%)$ \\
\hline Total & $24(10 \%)$ \\
\hline \multicolumn{2}{|l|}{ Academic pharmacy } \\
\hline Research & $1(0.4 \%)$ \\
\hline Education/Training & $6(2.5 \%)$ \\
\hline Total & $7(3 \%)$ \\
\hline Grand Total Job categories of the 189 pharmacists & $244(100 \%)$ \\
\hline
\end{tabular}

\subsection{Relevance of the studied topics to the daily work}

As shown in tables no 2, 3 and 4, the participants were asked to indicate relevance, of what they studied during their preservice education, to their current job. These questions were divided into 3 categories on the subjects available for students and covered basic sciences (table 2), pharmaceutical sciences (table 3) and subjects related to public health (table 4) respectively. The participant was given 3-point scale questions in regard to the named subjects and asked chose one of 4 choices: whether s/he used during daily work or did not use or can't decide or the subject in question was simply not studied in curriculum i.e. not applicable (NA).

\subsubsection{Basic sciences}

Table 2 shows that, among the basic sciences scored as follows: among the list of 16 sciences, only English language was identified being used by $>50 \%$ of participants $(61 \%)$ in their daily practice. All other sciences in the list ( 15 in number) were labelled as being used by only $<50 \%$. On the other hand, 12 out of 16 sciences were labelled as being "not used" by $>50 \%$ of participants. These sciences included: Physics ( $80 \%)$, Organic chemistry (76\%), Analytical Chemistry (76\%), Histology (75\%), Biology (74\%), Anatomy (73\%), General Chemistry (73\%), Microbiology (68\%), Botany (65\%), Pathology (64\%), Parasitology (58\%) and Physiology (57\%). Participants were divided between "using" and "not using" two sciences in their daily work. Over $40 \%$ of participants thought they used or not used Mathematics (46\% or $41 \%$ ) and Psychology (44\% or $42 \%$ ) respectively. 
Table No 2: Relevance of the studied basic science courses to 189 respondents' daily work.

$\begin{array}{lcccc}\text { Basic Sciences } & \text { Used } & \text { Undecided } & \text { Not used } & \text { N/A } \\ \text { Mathematics } & 87(46 \%) & 12(6 \%) & 78(41 \%) & 12(6 \%) \\ \text { Physics } & 16(9 \%) & 15(8 \%) & 152(80 \%) & 6(3 \%) \\ \text { Biology } & 28(15 \%) & 11(6 \%) & 139(74 \%) & 11(6 \%) \\ \text { English } & 116(61 \%) & 0 & 67(36 \%) & 6(3 \%) \\ \text { Physiology } & 51(27) & 18(10 \%) & 108(57 \%) & 12(6 \%) \\ \text { Anatomy } & 30(16 \%) & 12(6 \%) & 137(73 \%) & 10(5 \%) \\ \text { Histology } & 13(7 \%) & 23(12 \%) & 141(75 \%) & 12(6 \%) \\ \text { Pathology } & 45(24 \%) & 12(6 \%) & 120(64 \%) & 12(6 \%) \\ \text { Botany } & 1(0.5 \%) & 4(3 \%) & 122(65 \%) & 17(9 \%) \\ \text { Biochemistry } & 40(21 \%) & 68(36 \%) & 67(36 \%) & 14(7 \%) \\ \text { Psychology } & 83(44 \%) & 7(4 \%) & 79(42 \%) & 20(11 \%) \\ \text { General chemistry } & 23(12 \%) & 18(10 \%) & 138(73 \%) & 10(5 \%) \\ \text { Organic chemistry } & 19(10 \%) & 15(8 \%) & 143(76 \%) & 11(6 \%) \\ \text { Analytical chemistry } & 21(11 \%) & 17(9 \%) & 143(76 \%) & 8(4 \%) \\ \text { Microbiology } & 42(22) & 7(8 \%) & 128(68 \%) & 12(6 \%) \\ \text { Parasitology } & 56(30 \%) & 5(3 \%) & 109(58 \%) & 19(10 \%)\end{array}$

\subsubsection{Pharmaceutical sciences}

Table 3 shows how pharmaceutical sciences were perceived as being used or not by $>50 \%$ of the conferred pharmacists. Among the 19 subjects in the list, only Pharmacology was seen as "used" by $>50 \%$ of respondents (78\%). To a less scale, subjects seen by $>40 \%$ included Clinical Pharmacy (49\%), Pharmacy Practice (48) and Pharmacy Management (41\%). However, $>50 \%$ of respondents indicated that they did not use 9 out of the 19 pharmaceutical subjects and included: Pharmaceutics/Pharmaceutical Technology (76\%), BioPharmacy/Biopharmaceutics (75\%), Physical Pharmacy (73\%), Toxicology and First Aid (70\%), Pharmaceutical Administration and Management (68\%), Pharmaceutical Chemistry (68\%), Pharmacognosy (65\%), Pharmaceutical calculation (53\%) and Essential drug/National Medicines Policy (52\%). Professional Pharmacy was labelled as "not studied" by $77 \%$ of respondents.

Table No 3: Relevance of the studied pharmaceutical sciences courses to 189 respondents' daily work.

\begin{tabular}{lllll} 
Pharmaceutical Science & \multicolumn{1}{c}{ Used } & \multicolumn{1}{c}{ Undecided } & \multicolumn{1}{c}{ Not used } & Not studied \\
\hline Pharmaceutical calculation & $67(35 \%)$ & $10(5 \%)$ & $98(53 \%)$ & $14(7 \%)$ \\
Pharmaceutical administration \& management & $23(12 \%)$ & $18(9 \%)$ & $128(68 \%)$ & $20(11 \%)$ \\
Pharmaceutical chemistry & $34(18 \%)$ & $14(8 \%)$ & $129(68 \%)$ & $12(6 \%)$ \\
Pharmacognosy & $48(26 \%)$ & $6(3 \%)$ & $123(65 \%)$ & $12(6 \%)$ \\
Pharmaceutics / Pharmaceutical Technology & $15(8 \%)$ & $15(8 \%)$ & $144(76 \%)$ & $15(8 \%)$ \\
Bio-pharmacy /Biopharmaceutics & $18(10 \%)$ & $19(10 \%)$ & $142(75 \%)$ & $10(5 \%)$ \\
Physical pharmacy & $16(8 \%)$ & $22(12 \%)$ & $138(73 \%)$ & $13(7 \%)$ \\
Pharmacokinetics & $38(20 \%)$ & $7(4 \%)$ & $68(36 \%)$ & $76(40 \%)$ \\
Clinical pharmacy & $93(49 \%)$ & $6(3 \%)$ & $74(39 \%)$ & $16(9 \%)$ \\
Pharmacology & $147(78 \%)$ & $3(1.6 \%)$ & $18(9 \%)$ & $21(11 \%)$ \\
Pharmacy practice & $90(48 \%)$ & $4(2 \%)$ & $26(14 \%)$ & $69(36 \%)$ \\
Pharmacodynamics & $32(17 \%)$ & $9(5 \%)$ & $61(32 \%)$ & $87(46 \%)$ \\
Pharmacy management & $77(41 \%)$ & $10(5 \%)$ & $34(18 \%)$ & $68(36 \%)$ \\
Control \& regulation of pharmaceutical products & $63(33 \%)$ & $6(3 \%)$ & $30(16 \%)$ & $90(48 \%)$ \\
Instrumental analysis \& quality control & $21(11 \%)$ & $3(2 \%)$ & $82(43 \%)$ & $83(44 \%)$ \\
Toxicology and first aid & $23(12 \%)$ & $12(6 \%)$ & $132(70 \%)$ & $22(12 \%)$ \\
Professional pharmacy & $11(6 \%)$ & $9(5 \%)$ & $24(12 \%)$ & $145(77 \%)$ \\
Essential drug/national medicine policy (N =33) & $8(24 \%)$ & $5(15 \%)$ & $17(52 \%)$ & $3(9 \%)$ \\
Rational use of medicines (N=33) & $12(37 \%)$ & $8(24 \%)$ & $13(39 \%)$ & 0
\end{tabular}

\subsubsection{Public health-related subjects}

As shown in table 4, among the 4 subjects related to Public Health, none were found to have been "used" in daily work. More than $50 \%$ of respondents indicated that both Public Health and Graduate project were found to be "not used" by $61 \%$ and $59 \%$ respectively. Also, majority of respondents indicated they did not study Biostatistics (47\%) nor Computer (42\%). 
Table No 4: Relevance of studied courses related to public health to the daily work of pharmacists.

$\begin{array}{lllll}\text { Science } & \text { Used } & \text { Undecided } & \text { Not used } & \text { Missing } \\ \text { Biostatistics } & 11(6 \%) & 15(8 \%) & 74(39 \%) & 89(47 \%) \\ \text { Computer } & 74(39 \%) & 8(4 \%) & 28(15 \%) & 79(42 \%) \\ \text { Public Health } & 33(17 \%) & 21(11 \%) & 115(61 \%) & 20(11 \%) \\ \text { Graduate project } & 43(23 \%) & 19(10 \%) & 111(59 \%) & 16(8 \%)\end{array}$

\subsection{The application of the acquired skills}

The questionnaire presented a list of practical skills summarized and approximated to Yemen's pharmacy curricula [Jungnickel et al, 2009; Al-Worafi, 2014] and covered 13 skills pertaining to different competencies that pharmacist usually practice during daily work. Table 5 shows that among these 13 skills, 6 were labelled as have been "used" by $>50 \%$ of respondents and covered: drug dispensable skills (79\%), communication skills (79\%), listening skills $(78 \%)$, health education of public $(62 \%)$, working with other health team $(62 \%)$ and handling and managing drugs and medical supplies $(61 \%)$. On the other hand, more than $>50 \%$ of the respondents admitted "not using" 4 skills including following: compounding of medicines and mixtures skills (81\%), research skills (74\%), statistical skills (71\%), planning skills (62\%).

Table No 5: The use of the acquired skills of the pharmacists to the work environment $(\mathrm{N}=189)$

\begin{tabular}{lllll} 
Skills & \multicolumn{1}{c}{ Used } & Undecided & Not used & No studied \\
Compounding of medicines \& mixtures & $20(11 \%)$ & $12(6 \%)$ & $153(81 \%)$ & $4(2 \%)$ \\
Communication skills & $149(79 \%)$ & $4(2 \%)$ & $27(14 \%)$ & $9(5 \%)$ \\
Listening skills & $148(78 \%)$ & $1(1 \%)$ & $28(15 \%)$ & $12(6 \%)$ \\
Health education skills & $117(62 \%)$ & $1(1 \%)$ & $59(31 \%)$ & $12(6 \%)$ \\
Research skills & $31(16 \%)$ & $4(2 \%)$ & $140(74 \%)$ & $14(8 \%)$ \\
Statistical skill & $21(11 \%)$ & $20(11 \%)$ & $134(71 \%)$ & $14(7 \%)$ \\
Planning skill & $32(17 \%)$ & $24(13 \%)$ & $118(62 \%)$ & $15(8 \%)$ \\
Drugs dispensing skills & $149(79 \%)$ & $4(2 \%)$ & $29(15 \%)$ & $7(4 \%)$ \\
Managerial skill & $62(33 \%)$ & $13(7 \%)$ & $82(43 \%)$ & $32(17 \%)$ \\
Managing therapeutic outcomes of patients & $74(39 \%)$ & $13(7 \%)$ & $81(43 \%)$ & $21(11 \%)$ \\
Monitoring patients' therapeutic progress & $79(42 \%)$ & $9(5 \%)$ & $79(42 \%)$ & $22(11 \%)$ \\
Working with other health care providers. & $118(62 \%)$ & $11(6 \%)$ & $45(24 \%)$ & $15(8 \%)$ \\
Handling \& managing drug and med. supplies & $114(61 \%)$ & $10(5 \%)$ & $48(25 \%)$ & $17(9 \%)$
\end{tabular}

\subsection{Practice of behavioural skills:}

As shown in table 6, most of participants reported that they are either fully or partially trained on the 7 listed behavioural skills. All these skills can not be traced to "subjects" studied during preservice education. These hidden curricular components need to be clearly labelled and emphasized.

Table No 6: Behavioural skills that the pharmacists were trained about in college and practicing in their work

\begin{tabular}{lllll} 
Behavioural skills & Trained & $\begin{array}{l}\text { Partially } \\
\text { trained }\end{array}$ & $\begin{array}{l}\text { Not } \\
\text { trained }\end{array}$ & $\begin{array}{l}\text { Not } \\
\text { studied }\end{array}$ \\
\hline Behavior with pharmacy team members & $119(63 \%)$ & $45(24 \%)$ & $23(12 \%)$ & $2(1 \%)$ \\
Behavior with health team members & $82(43 \%)$ & $75(40 \%)$ & $30(16 \%)$ & $2(1 \%)$ \\
Behavior with supervisors \& employees & $110(58 \%)$ & $58(31 \%)$ & $15(8 \%)$ & $6(3 \%)$ \\
Team work process behavior & $144(76 \%)$ & $31(17 \%)$ & $6(3 \%)$ & $8(4 \%)$ \\
Behavior with patients in drug dispensing & $101(53 \%)$ & $66(35 \%)$ & $17(9 \%)$ & $5(3 \%)$ \\
Behavior with patients in providing drug information & $89(47 \%)$ & $80(42 \%)$ & $17(9 \%)$ & $3(2 \%)$ \\
Behavior with patients in conducting health education & $56(30 \%)$ & $73(39 \%)$ & $57(30 \%)$ & $3(1 \%)$
\end{tabular}

\section{Discussion}

Significant changes in national health care systems worldwide are fueling the critical examination of how health professionals are educated and trained, what they learn and how they learn it. In a recent study, the first two of the eight validated challenges address the areas on graduate's preparedness for practice and pharmacy education accreditation [Bader et al, 2017]. The movement to reform the pharmacy education started gradually and goes back to 1910 when Flexner's report demanded reorganization of medical education [Flexner, 1910]. Similar to medicine, the profession of pharmacy began as a system of apprenticeship and during the early $20^{\text {th }}$ century, remnants of the apprenticeship system continued with students and graduates often required to complete a requisite period of practice experience under a practitioner pharmacist. The Philadelphia College of Pharmacy, established in 1821, was the first formal college organized to train pharmacists [Crass and Romanelli, 2018]. In response to the 1910 Flexner's call for regulating the medical education, the accrediting body for pharmacy, the American Council on Pharmaceutical Education, was established in 1932, (now is called Am Council for Pharmacy Education), to set 
standards for a baccalaureate degree in pharmacy. Subsequently, the Council proposed that the profession adopt a six-year entry-level curriculum and met with resistance, a compromise was struck and the five-year Bachelor of Science degree in Pharmacy was adopted a two-year post-graduate clinical practice. Driven in part by a shift in pharmacy practice from product- to patient-oriented and the introduction of the concept of pharmaceutical care, the profession moved to establish a six-year PharmD degree as the entry-level practice credential beginning in 2000 [Crass and Romanelli, 2018]. The introduction of the extended period of study allowed to add subjects related to clinical pharmacy, community pharmacy and industrial pharmaceutical sciences. In 1986 new set of medically oriented courses were introduced in UK initiating the role of health care-giver [Anderson, 2005]. The factors contributing to these changes are presented by WHO indicating that it is essential that all health professionals are appropriately and adequately prepared to support a global policy framework for health [WHO, 1994].

The interest in pharmacy as a focal point for a global health policy framework stems from WHO's report of Delhi WHO meeting in 1988 [WHO, 1994]. Through further WHO collaboration with the work of the FIP, the International Pharmaceutical Students Federation-IPSF and others, these efforts have been further pursed and supported via regional and national efforts. Sufficient background information gathered to provide guidance to pharmaceutical educators regarding the preparation of students for contemporary and future careers in pharmacy services. in the form of the 7-Star roles of pharmacist [WHO, 1997]. In more recent years, further development of pharmacy education curricula has taken place to address not only the content but the educational strategies and methodologies and outcomes to include: evidence-based pharmacotherapeutic decision-making, integration methodologies to improve learning outcomes. active learning strategies, multiple strategies including cooperative, team-based, problem-based, and case-based learning approaches and other strategies [Crass and Romanelli, 2018].

The results obtained in this study show that majority of practicing pharmacists working in 5 different work settings in Aden, Yemen, marked the existence of a weak linkage between the topics they studied in their preservice education and their daily work demands. The sample of the respondents were working in almost all pharmacy settings which covered community pharmacy, hospital pharmacy, industrial pharmaceutics, management of medicines and medical supplies and academic pharmacy. Out of 16 basic sciences that these pharmacists studied during their preservice education, only one (English language) was used by $>50 \%$ of them in their daily work. The same is applied on the study of pharmaceutical and public health sciences. They should be incorporated and integrated under themes of systems so that pharmacist can use whenever a task is performed at work. Astonishingly, and among the 19 pharmaceutical subjects in the list, only Pharmacology was seen as "used" by $>50 \%$ of respondents (78\%) in their work. To a less scale, subjects seen by $<50 \%$ included Clinical Pharmacy (49\%), Pharmacy Practice (48) and Pharmacy Management (41\%). However, $>50 \%$ of respondents indicated that they did not use 9 out of the 19 pharmaceutical subjects and included: Pharmaceutics / Pharmaceutical Technology (76\%), Bio-Pharmacy/Biopharmaceutics (75\%), Physical Pharmacy (73\%), Toxicology and First Aid (70\%), Pharmaceutical Administration and Management (68\%), Pharmaceutical Chemistry (68\%), Pharmacognosy (65\%), Pharmaceutical calculation (53\%) and Essential drug/National Medicines Policy (52\%). Also, among the 4 subjects related to Public Health, none were found to have been "used" in daily work. More than $50 \%$ of respondents indicated that both Public Health and Graduate project were found to be "not used" by $61 \%$ and $59 \%$ respectively. Also, majority of respondents indicated they did not study Biostatistics (47\%) nor Computer (42\%). These results show how majority of subjects studied in pre-service education are seen "useless" to graduates because they perform different tasks and competencies during daily work. In the same order, and among the 13 skills shown in table 5 , only 6 were labelled as have been "used" by $>50 \%$ of respondents and covered: drug dispensable skills (79\%), communication skills (79\%), listening skills (78\%), health education of public $(62 \%)$, working with other health team (62\%) and handling and managing drugs and medical supplies (61\%); and more than $>50 \%$ of the respondents admitted "not using" 4 other skills including following: compounding of medicines and mixtures skills $(81 \%)$, research skills $(74 \%)$, statistical skills $(71 \%)$, planning skills (62\%). Furthermore, and as shown in table 6 , most of participants reported that they are either fully or partially trained on all the 7 behavioural skills.

When $>50 \%$ of respondents indicated that they did not use large number of subjects or sciences in their daily work, such a statement indicates a "false" thinking of meaning that elements or facts of these sciences were not used as a such or as a "separate" entity. The respondents must have used such elements from these sciences as part of the "integrated" elements embedded within the different and many tasks performed in work. This situation requires a clearer change in curriculum towards integrated subjects rather than separate subjects. These relevant components from the basic, pharmaceutical and population health sciences plus the skills and attitudes need to be emphasized and integrated within the learning process in a way that assimilates the tasks required to perform in work [Alsheikh et at, 2018]. Cognitive, technical and behavioral skills need to be emphasized and clearly labelled in curriculum rather than kept as "hidden" elements with curricular opportunities for al students to practice [Alsheikh et al, 1999].

The Nanjing Declaration indicated that "Experiential Education" should be the essential elements of future pharmacy education [FIP, 2017]. Such educational environment creates learning and training opportunities for 
students to do-by-practicing the targeted competencies of the pharmacy graduates. The newly introduced curriculum in Aden's faculty of pharmacy, seems to have included a limited number of changes to curriculum in omitting redundant subjects, introducing seminars and training and research activities. However, the curriculum kept the dominance of theoretical "didactive teaching" compared to student-centred learning opportunities [Aden University, 2018]. The upgrading of learning activities towards achieving the "experiential learning" seems to be still far away from being implemented in Aden, and in other pharmacy colleges in Yemen and across the globe.

Reforming the pre-service pharmacy curriculum is under debate with many options available [FIP, 2017]. In the light of the presented results, the 7-star roles can be tested as it has been introduced in 1997 i.e. two years after the establishment of the Faculty of Pharmacy in Aden University. Analyzing the 7 roles into its functions can lead to proposing relevant educational strategies that can be considered for the reform of the pharmacy pre-service education in order to enable and empower students to acquire optimum competencies upon graduation. Competencies needed to shift pharmacy education from the prevailing drug-based to patient and systems-based are well presented [Noble et al, 2011; McLaughlin et al, 2017]. Table no 7 shows how such analysis can lead to deriving educational strategies that we propose to adopt in a possible curricular reform based on the WHO's 7-star roles of the pharmacist [WHO, 1997].

Table No 7: Analysis of the 7-star pharmacist's roles and derivation of educational reform strategies

\begin{tabular}{|c|c|c|c|}
\hline $\begin{array}{l}\text { Pharmacist } \\
\text { Roles }\end{array}$ & What it means [WHO, 1994] & $\begin{array}{l}\text { Curricular learning } \\
\text { approaches }\end{array}$ & $\begin{array}{l}\text { Educational } \\
\text { strategies }\end{array}$ \\
\hline Caregiver & $\begin{array}{l}\text { The pharmacist provides caring services. } \\
\text { Whether these services are clinical, analytical, } \\
\text { technological or regulatory, the pharmacist must } \\
\text { be comfortable interacting with individuals and } \\
\text { populations. The pharmacist must view his or } \\
\text { her practice as integrated and continuous with } \\
\text { those of the health care system and other } \\
\text { pharmacists. Services must be of highest } \\
\text { quality. }\end{array}$ & $\begin{array}{l}\text { Student-dominant } \\
\text { experiential learning and } \\
\text { training sessions on clinical, } \\
\text { analytical, technological or } \\
\text { regulatory structured sessions } \\
\text { of services using } \\
\text { pharmaceutical sciences as } \\
\text { content. }\end{array}$ & $\begin{array}{l}\text { Patient } \\
\text { Centered } \\
\text { Education }\end{array}$ \\
\hline $\begin{array}{l}\text { Decision- } \\
\text { maker }\end{array}$ & $\begin{array}{l}\text { The appropriate, efficacious and cost-effective } \\
\text { use of resources (e.g. personnel, medicines, } \\
\text { chemicals, equipment, procedures, practices) } \\
\text { should be at foundation of the pharmacist's } \\
\text { work. Achieving this goal requires the ability to } \\
\text { evaluate, synthesize and decide the most } \\
\text { appropriate course of action. }\end{array}$ & $\begin{array}{l}\text { Structured } \begin{array}{r}\text { discussion } \\
\text { sessions and learning }\end{array} \\
\text { opportunities scenarios for } \\
\text { student to practice skills of } \\
\text { managing different resources } \\
\text { using pharmaceutical } \\
\text { sciences as content. }\end{array}$ & $\begin{array}{l}\text { Life-Long } \\
\text { Learning }\end{array}$ \\
\hline Com'cator & $\begin{array}{l}\text { The pharmacist is in an ideal position between } \\
\text { physician and patient. As such, s/he must be } \\
\text { knowledgeable and confident while interacting } \\
\text { with other health professionals and the public. } \\
\text { Communication involves verbal, non-verbal, } \\
\text { listening and writing skills. }\end{array}$ & 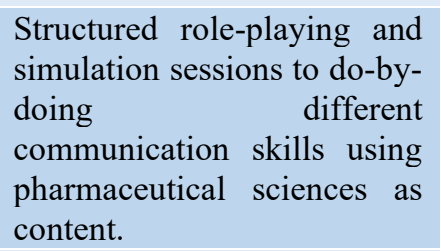 & $\begin{array}{l}\text { Student } \\
\text { Centered } \\
\text { Education }\end{array}$ \\
\hline Leader & $\begin{array}{l}\text { Whether the pharmacist finds him/herself in } \\
\text { multidisciplinary (e.g. team) caring situations or } \\
\text { in areas where other health care providers are in } \\
\text { short supply or non-existent, s/he is obliged to } \\
\text { assume a leadership position in the overall } \\
\text { welfare of the community. Leadership involves } \\
\text { compassion and empathy as well as the ability } \\
\text { to make decisions, communicate, and manage } \\
\text { effectively. }\end{array}$ & $\begin{array}{l}\text { Learning/training structured } \\
\text { sessions of multidisciplinary } \\
\text { team members addressing } \\
\text { leadership skills using } \\
\text { pharmaceutical sciences as } \\
\text { content. }\end{array}$ & $\begin{array}{l}\text { Community } \\
\text { Oriented } \\
\text { Programme }\end{array}$ \\
\hline Manager & $\begin{array}{l}\text { The pharmacist must effectively manage } \\
\text { resources (human, physical and fiscal) and } \\
\text { information; s/he must also be comfortable } \\
\text { being managed by others, whether and employer } \\
\text { or manager/leader of health care team. More and } \\
\text { more, information and its related technology } \\
\text { will provide challenges to the pharmacist as s/he } \\
\text { assumes greater responsibility for sharing } \\
\text { information about medicines and related } \\
\text { products. }\end{array}$ & $\begin{array}{l}\text { Learning/training structured } \\
\text { sessions of multidisciplinary } \\
\text { team members addressing } \\
\text { management skills dealing } \\
\text { with resources and } \\
\text { information using } \\
\text { pharmaceutical \& population } \\
\text { health sciences as content. }\end{array}$ & $\begin{array}{l}\text { Systems } \\
\text { Based } \\
\text { Education }\end{array}$ \\
\hline
\end{tabular}




\begin{tabular}{|c|c|c|c|}
\hline $\begin{array}{l}\text { Pharmacist } \\
\text { Roles }\end{array}$ & What it means [WHO, 1994] & $\begin{array}{l}\text { Curricular } \\
\text { approaches }\end{array}$ & $\begin{array}{l}\text { Educational } \\
\text { strategies }\end{array}$ \\
\hline $\begin{array}{l}\text { Life-long } \\
\text { learner }\end{array}$ & $\begin{array}{l}\text { It is no longer possible to learn all one must learn } \\
\text { in school in order to practice a career as a } \\
\text { pharmacist. The concepts, principles and } \\
\text { commitment to life-long learning must begin } \\
\text { while attending pharmacy college and must be } \\
\text { supported throughout the pharmacist's career. } \\
\text { Pharmacists should learn how to learn. }\end{array}$ & $\begin{array}{l}\text { Studying pharmaceutical } \\
\text { sciences in structured } \\
\text { sessions to create student's } \\
\text { learning needs with 7-jump } \\
\text { PBL sessions to allow } \\
\text { practicing-by-doing self- } \\
\text { assessment, own gaps, } \\
\text { learning objectives, self- } \\
\text { learning to fill gaps. }\end{array}$ & $\begin{array}{l}\text { Life-Long } \\
\text { Learning }\end{array}$ \\
\hline Teacher & $\begin{array}{l}\text { The pharmacist has a responsibility to assist } \\
\text { with the education and training of future } \\
\text { generations of pharmacists. Participating as a } \\
\text { teacher not only imparts knowledge to others, it } \\
\text { offers an opportunity for the practitioner to gain } \\
\text { new knowledge and to fine-tune existing skills. }\end{array}$ & $\begin{array}{l}\text { At end of the 7-jump } \\
\text { sessions, presentation of } \\
\text { products in form of teaching } \\
\text { and discussing with team } \\
\text { members followed by self } \\
\text { and peer-evaluation. }\end{array}$ & $\begin{array}{l}\text { Full } \\
\text { Integration }\end{array}$ \\
\hline
\end{tabular}

These educational strategies include provision of ample opportunities for students to apply what they learn concurrently through the entire years of study. In other words, a curriculum that offers opportunities for all students to achieve the "experiential learning' based on the following 6 educational strategies: community-oriented; student-centered; life-long learning; patient-based; systems-based; fully integrated educational programme (figure 3). Further studies are needed to elaborate on these proposed strategies and approaches to achieve the targeted outcomes.

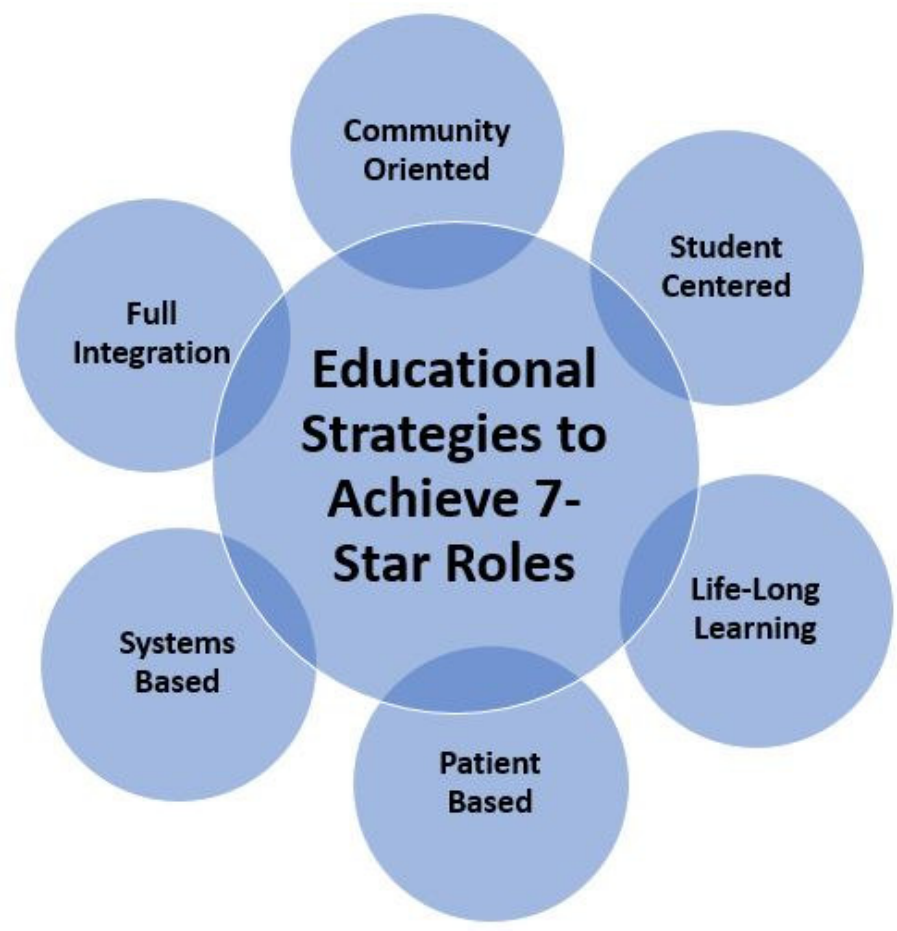

Figure 3: The 6 educational strategies contributing to achieving the pharmacist's 7-star roles.

\section{Conclusions}

The study showed that pharmacists working in Aden, Yemen, practice in five pharmacy settings in community, pharmaceutical industry, hospital, management and academic pharmacy settings. Majority of respondents admitted existence of weak link between their daily work to knowledge, skills and attitudes they studied at their pre-service education. Attempts to reform pharmacy curriculum is still not decisive with attempts of incomplete fulfilling of the requirement of knowledge, skills and attitude needed in different work settings. The study proposes analysis of the WHO's 7-star roles of the pharmacist and recommends a generic set of educational strategies that any reformed pharmacy curriculum should address to fulfil a fit-for-purpose graduate. 


\section{References}

Aden University. 'Study plan for the bachelor degree in Pharmacy at faculty of pharmacy'. Offset Document; Aden: $\quad$ Aden University 2018. https://drive.google.com/file/d/1MifyUU0yiRhLSyIWilL_UOr6xCV99PxU/view. Accessed on 20/03/2020.

Alsheikh, GY Mustafa; Allan, Abed IM; Sulaiman, Nabeel D. Development of student's self-reliance and decisionmaking during study in Tikrit University College of Medicine. Med J Tikrit Univ 1999; 5:117-122. DOI: 10.13140/RG.2.1.3375.3042

Alsheikh, G; Mustafa, O; Kadhim, TJ; Alzubaidi, RS; Alalak, MM; Rowandozi, I. (2018) Evaluation of the Curricula of Iraqi medical colleges in light of innovation of medical education. Journal of AlFath for Educational and Psychological Research, 73 (March) 2018, 41-83. DOI: 10.23813/FA/73/3

Al-Worafi YM. Pharmacy education in Yemen. American Journal of Pharmaceutical Education 2013; 77 (3) Article 65; 1-2.

Al-Worafi YM. The challenges of pharmacy education in Yemen. American Journal of Pharmaceutical Education 2014; 78 (8) Article 146: 1-5.

Anderson, S. 'Making Medicines: A brief history of pharmacy and pharmaceuticals.' London: Pharmaceutical Press. 2005. ISBN-10: 0853695970

Bader LR, McGrath S, Rouse MJ, Anderson C. A conceptual framework toward identifying and analyzing challenges to the advancement of pharmacy. Res Social Adm Pharm; 2017; 13(2): 321-331. DOI: 101016/j.sapharm.2016.03.001

Centre for Pharmacy Postgraduate Education-CPPE. Consultation skills for pharmacy practice: Practice standards for England. 2014. http://www.consultationskillsforpharmacy.com/docs/docc.pdf. Accessed on 22/04/2020.

Crass, RL and Romanelli, F. Curricular reform in pharmacy education through the lens of the Flexner report of 1910. American Journal of Pharmaceutical Education. 2018; 82(7): Article 6804. DOI: 10.5688/ajpe6804

FIP-International Pharmaceutical Federation. 'Statement of policy on good pharmacy education practice.' The Hague: FIP; 2000. https://www.fip.org/file/1518. Accessed on 30/04/2019.

FIP-International Pharmaceutical Federation. 'Nanjing Declaration: Transforming pharmacy and pharmaceutical sciences education in the context of workforce development.' Cluster 5: Experiential education. The Hague: FIP; 2017. https://www.fip.org/files/content/priority-areas/workforce/nanjing-statements.pdf. Accessed $27 / 02 / 2018$

Flexner, A. (1910) 'Medical Education in the United States and Canada Bulletin Number Four (The Flexner Report)', Carnegie Bulletin, p. 364. DOI: 10.1001/JAMA.1943.02840330031008.

Hepler CD and Strand LM. Opportunities and responsibilities in pharmaceutical care. Am J Hosp Pharm. 1990; 47:533-543.

Jungnickel PW, Kelley KW, Hammer DP, Haines ST, and Marlowe KF. Addressing competencies for the future in the professional curriculum. American Journal of Pharmacy Education. 2009; 73(8); Article 156: 1-15.

Kheir N, Zaidan M, Younes H, El Hajj M, Wilbur K and Jewesson PJ. Pharmacy education and practice in 13 Middle Eastern countries. American Journal of Pharmaceutical Education. 2008; 72 (6); Article 133: 1-13.

McLaughlin JE, Bush AA, Rodgers PT, Scott MA, Zomorodi M, Pinelli NR, Roth MT. Exploring the requisite skills and competencies of pharmacists needed for success in an evolving health care environment. American Journal of Pharmaceutical Education. 2017; 81 (6) Article 116: 1-10.

Noble C, O'Brien M, Coombes I, Nicholas Shaw P, and Nissen L. Concept mapping to evaluate an undergraduate pharmacy curriculum. American Journal of Pharmaceutical Education. 2011; 75 (3) Article 55: 1-11.

Toklu HZ and Hussain A. The changing face of pharmacy practice and the need for a new model of pharmacy education. J Young Pharm. 2013; 5: 38-40. DOI: 10.1016/j.jyp.2012.09.001

World Health Organization. 'The role of the pharmacist in the health care system: Report of a WHO Consultative Group, New Delhi, India, 13-16 December 1988.’1994; Geneve: World Health Organization Document No. WHO/PHARM/94.569.

https://apps.who.int/iris/bitstream/handle/10665/59169/WHO_PHARM_94.569.pdf?sequence=1\&isAllowe $\mathrm{d}=\mathrm{y}$ Accessed 28/08/2019.

World Health Organization. 'Ninth General Programme of Work covering the period 1996-2001.' 1994; Geneve: World

Health

Organization. https://apps.who.int/iris/bitstream/handle/10665/39897/9241800119.pdf?sequence=1\&isAllowed=y Accessed 28/08/2019.

World Health Organization. 'The role of the pharmacist in the health care system; Preparing the future pharmacist: curricular development.' WHO Report Document no. WHO/PHARM/97/599. Geneve: WHO; 1997. https://apps.who.int/iris/bitstream/handle/10665/63817/WHO_PHARM_97_599.pdf?sequence=1\&isAllowe $\mathrm{d}=\mathrm{y}$ Accessed on 20/10/2019. 